\title{
Free and protected soil organic carbon dynamics respond differently to abandonment of mountain grassland
}

\author{
S. Meyer ${ }^{1}$, J. Leifeld ${ }^{1}$, M. Bahn ${ }^{2}$, and J. Fuhrer ${ }^{1}$ \\ ${ }^{1}$ Agroscope Research Station Reckenholz-Tänikon ART, Air Pollution/Climate Group, Reckenholzstrasse 191, \\ 8046 Zürich, Switzerland \\ ${ }^{2}$ Institute of Ecology, University of Innsbruck, Sternwartestrasse 15, 6020 Innsbruck, Austria \\ Correspondence to: J. Leifeld (jens.leifeld@art.admin.ch)
}

Received: 24 August 2011 - Published in Biogeosciences Discuss.: 6 October 2011

Revised: 13 January 2012 - Accepted: 7 February 2012 - Published: 23 February 2012

\begin{abstract}
Land-use change (LUC) and management are among the major driving forces of soil carbon (C) storage. Abandonment of mountain grassland promotes accumulation of aboveground biomass and litter, but related responses of soil organic matter (SOM) dynamics are uncertain. To determine SOM-C turnover we sampled $0-10 \mathrm{~cm}$ of soils in the European Alps along two land-use gradients (hay meadows, grazed pastures and abandoned grasslands) of different management intensity. A first land-use gradient was located at Stubai Valley (MAT: $3{ }^{\circ} \mathrm{C}$, MAP: $1097 \mathrm{~mm}$ ) in Austria and a second at Matsch Valley (MAT: $6.6^{\circ} \mathrm{C}$, MAP: $527 \mathrm{~mm}$ ) in Italy. We estimated $\mathrm{C}$ input and decomposition rates of water-floatable and free particulate organic matter (wPOM, fPOM $<1.6 \mathrm{~g} \mathrm{~cm}^{-3}$ ) and aggregate-occluded particulate and mineral-associated organic matter (oPOM $<1.6 \mathrm{~g} \mathrm{~cm}^{-3}, \mathrm{mOM}>1.6 \mathrm{~g} \mathrm{~cm}^{-3}$ ) using bomb radiocarbon.

In mountain grasslands average $\mathrm{C}$ turnover increased from roots $(3 \mathrm{yr})<$ wPOM $(5 \mathrm{yr})<$ fPOM $(80 \mathrm{yr})<$ oPOM $(108 \mathrm{yr})<\operatorname{mOM}(192 \mathrm{yr})$. Among SOM fractions the turnover of fPOM-C varied most in relation to management. Along both land-use gradients $\mathrm{C}$ input pathways shifted from root-derived towards litter-derived $\mathrm{C}$. The $\mathrm{C}$ input rates of both wPOM-C and fPOM-C were affected by land management at both sites. In contrast, oPOM-C and mOM-C dynamics remained relatively stable in response to grassland abandonment. Carbon accumulation rates of free POM decreased strongly with time since LUC (10, 25 and $36 \mathrm{yr}$ ). For wPOM-C, for example, it decreased from $7.4>2.2>0.8 \mathrm{~g} \mathrm{C} \mathrm{m}^{-2} \mathrm{yr}^{-1}$. At both sites, most $\mathrm{C}$ was sequestered in the first years after LUC and free POM reached new steady state within $20-40 \mathrm{yr}$.
\end{abstract}

We conclude that $\mathrm{w}$-and $\mathrm{PPOM}-\mathrm{C}$ vs. oPOM-C dynamics respond differently to grassland management change and thus POM does not represent a homogeneous SOM fraction.
Sequestered C is stored in the labile POM and not stabilized in the long-term. Thus, it is unlikely that abandonment, the dominant form of LUC in the European Alps, provides a substantial net soil C sink.

\section{Introduction}

The potential for carbon (C) storage is high in grassland soils and both management type and intensity influence the efficiency of C storage (Conant et al., 2001; Post and Kwon, 2000). Throughout the European Alps ongoing socio-economic changes have strongly influenced land-use and management intensity (Cernusca et al., 1999; Tappeiner et al., 2008) which in turn induced fundamental changes in ecosystem structure and functioning (Tasser et al., 2005). While management cessation leads to an accumulation of live and dead aboveground plant biomass in mountain grasslands (Tasser and Tappeiner, 2002; Tasser et al., 2005; Gamper et al., 2007) related responses of soil organic matter (SOM) are contradictory (Rubatscher, 2008; Martinsen, 2011; Leifeld and Fuhrer, 2009; Steffens et al., 2011) because of differences in management intensity, such as mowing and grazing frequencies, and time since land-use change (LUC). Related effects on rates of soil $\mathrm{C}$ changes are still uncertain.

Litter decomposition studies along gradients of grassland management intensity showed that with abandonment reduced litter quality (wide $\mathrm{C} / \mathrm{N}$ ratio, high lignin and low nutrient content, higher proportion of fungal biomass) (Zeller et al., 2001; Gamper et al., 2007) retards decomposition and induces an accumulation of relatively undecomposed plant litter. Schmitt et al. (2010) monitored net ecosystem exchange of $\mathrm{CO}_{2}$, gross primary productivity and ecosystem 


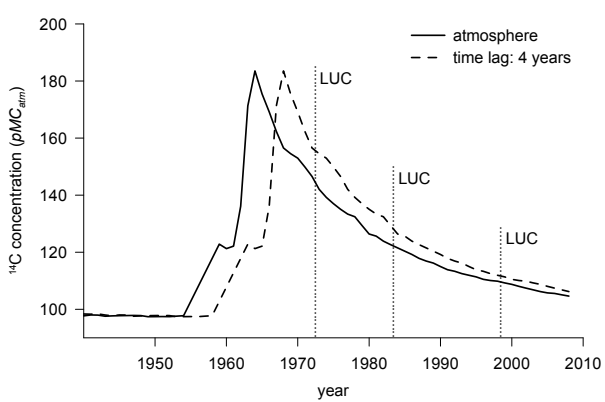

(a)

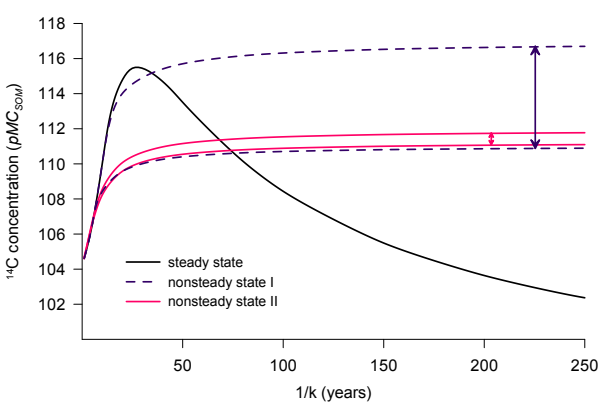

(b)

Fig. 1. (a) Time record of the ${ }^{14} \mathrm{C}$ concentration in the Northern Hemisphere (percent modern carbon: $\mathrm{pMC}$ atm $=\Delta{ }^{14} C_{\mathrm{atm}} / 1000+1$ ). The time lag refers to the time period between photosynthetic fixation and addition to soil organic matter (SOM), which is necessary to consider for all root-derived SOM-carbon (C). The atmospheric record, where turnover calculations are based on, is shifted by the lag time value, here 4 yr. Vertical dotted lines indicate times of land-use change (LUC) in 1972, 1983 and 1998.

(b) The predicted ${ }^{14} \mathrm{C}$ concentrations in 2008 for a homogeneous SOM fraction ( $\mathrm{pMC}_{\mathrm{SOM}}$ ) as function of turnover times $1 / k$, where $k$ is the decomposition rate. The curves represent results for steady-state and accumulation models. The curves produced by accumulation model are based on a fast and slow decomposition rate for the initial $\mathrm{C}$ stock and describe two scenarios: nonsteady state $\mathrm{I}$ is based on little $\mathrm{C}$ accumulation and nonsteady state II is based on high $\mathrm{C}$ accumulation. The more $\mathrm{C}$ has been accumulated the less important is the $\mathrm{C}$ dynamic of the initial $\mathrm{C}$ stock for the analyzed time periods.

respiration rates in subalpine grasslands and found that all measures decreased with decreasing land-use intensity and concluded that abandonment leads to reduced productivity and $\mathrm{C}$ exchange between soil and atmosphere. Decomposition and respiration studies allow to analyze $\mathrm{C}$ dynamics on hourly to monthly basis and thus predominantly quantify the short-term $\mathrm{C}$ turnover. Both methods integrate over SOM fractions varying in $\mathrm{C}$-cycling time, and it has proven difficult to establish a direct link between litter turnover, respiration measurements and SOM-C dynamics (von Lützow et al., 2007; Torn et al., 2009).

To derive SOM-C dynamics in response to LUC we used bomb radiocarbon, a tool to estimate $\mathrm{C}$ exchange on decadal timescales. Bomb radiocarbon reflects the time since ${ }^{14} \mathrm{C}$ atoms, produced by atmospheric nuclear weapons testing in the late 1950s and early 60s (Fig. 1a), were fixed from the atmosphere by plants. After adding a time lag between photosynthetic fixation and $\mathrm{C}$ storage in SOM, the degree to which bomb radiocarbon is found in SOM fractions provides a direct measure of decomposition rates (Trumbore, 2009). Lag times are difficult to measure but can be estimated from root$\mathrm{C}$ turnover and should be incorporated into $\mathrm{C}$ models (Torn et al., 2009). Gaudinski et al. (2000) estimated that the C in fine roots in temperate forest soils was fixed on average $7 \pm 1 \mathrm{yr}$ ago. One draw-back using bomb radiocarbon as an indicator of soil $\mathrm{C}$ exchange rates arises from the shape of the atmospheric record curve leading to two different time allocations for the same ${ }^{14} \mathrm{C}$ concentration: one before and one after the bomb spike in 1963. Thus, it is essential to use models to derive decomposition estimates from radiocarbon signature and compare fluxes with estimated rates of $\mathrm{C}$ inputs such as litter quantity and quality, and losses such as respira- tion (Trumbore, 2009). However, we know of no such study in abandoned grasslands, which is the dominant form of LUC in the European Alps (Tappeiner et al., 2008; Zimmermann et al., 2010).

While soil respiration measurements overestimate SOM turnover rates, ${ }^{14} \mathrm{C}$ measurements on bulk soil clearly underestimate C fluxes (Gaudinski et al., 2000; Torn et al., 2009). Decomposition rates are biased towards the slow-cycling mineral-associated $\mathrm{C}$ that usually builts the major proportion of SOM-C. Therefore, modeling ecosystem C accumulation and turnover requires the separation of homogeneous SOM fractions in terms of C-cycling time. Physical fractionation by density has proven particularly useful to identify meaningful soil fractions to LUC with or without soil mechanical disturbance (Golchin et al., 1994b; Six et al., 1998). The procedure takes advantage of the differences in density between less degraded particulate organic matter (POM) and comparably more decomposed mineral-associated organic matter (mOM).

Previous studies on mountain grasslands (Leifeld and Fuhrer, 2009; Martinsen, 2011) show contrasting responses of POM to management intensity, which is on the one hand attributed to differences in grassland type, management intensity and time since LUC, but on the other hand illustrates that POM is most probably not a chemically and physically homogeneous SOM fraction. The aggregate-based isolation of free and occluded aggregate organic matter provides additional information on microbial and physical processes that influence turnover and stability of SOM. Studies that divided POM into sub-fractions show that free and occluded POM are functionally specific pools and free POM responds much stronger to changes in grassland management intensity than 
occluded POM (Steffens et al., 2011), partly because differences in aggregation are minimal in grassland ecosystems (Meyer et al., 2012).

Like all chemical and biochemical processes microbial decomposition of SOM is not only dependent on litter quality (Coûteaux et al., 1995) but shows feedbacks with temperature and moisture (Davidson and Janssens, 2006). However, the effects of LUC on SOM-C storage and dynamics can be larger than those of climate (Torn et al., 2009; Schindlbacher et al., 2010).

Average above-ground phytomass has been shown to decrease from meadows to grassland abandoned for about $30 \mathrm{yr}$ by a factor of 2.2-2.4 (Gamper et al., 2007; Rubatscher, 2008). The $\mathrm{C} / \mathrm{N}$ ratios of plant biomass in managed grasslands were in the range of 20-27 and increased up to 35 towards abandonment consistent with an increase in dwarf shrubs (Rubatscher, 2008). Additionally litter-C increased fivefold (Gamper et al., 2007). As changes in aboveground biomass influence belowground microbial community composition (Wardle et al., 2004) and POM stocks depend upon mineralization of plant residues, we expect a response of $\mathrm{POM}$ to management cessation.

It is the goal of this paper to study effects of management reduction in subalpine grasslands on $\mathrm{C}$ input and decomposition rates of SOM. We hypothesize that POM decomposition rates would decrease with abandonment and thus SOM stocks would increase. Using bomb radiocarbon we additionally gain information on relevant time periods for $\mathrm{C}$ accumulation. We applied physical fractionation to soils from a land-use gradient including hay meadow, grazed pasture and abandoned grassland in two climatically different subalpine regions in the European Alps. Grasslands at one site were used in the context of earlier studies on various aspects of the C cycle (Bahn et al., 2006, 2008; Rubatscher, 2008; Schmitt et al., 2010). This allows comparison of fluxes derived from respiration measurements versus estimated rates implied from the SOM-C stocks and radiocarbon turnover modeling.

\section{Methods}

\subsection{Site description and soil sampling}

The study was carried out at two sites in cool temperate climate in the European Alps, each comprising a hay meadow, a pasture, and an abandoned grassland, but differing in temperature and precipitation. Table 1 summarizes site and soil characteristics. Using a gradient of decreasing management intensity we substituted time by space in order to analyze in parallel three different grassland systems at two regions. A first land-use gradient is located at a moist site in the Stubai Valley in Tyrol (Austria) at 1820-2000 m a.s.l. (Stubai site). A second, warmer and drier site is located in the inner-alpine Matsch Valley in South Tyrol (Italy) at 1790-
$1890 \mathrm{~m}$ a.s.l. (Matsch site). At the two sites, mean annual precipitation is $1097 \mathrm{~mm}$ and $527 \mathrm{~mm}$, and mean annual temperature is $3{ }^{\circ} \mathrm{C}$ and $6.6^{\circ} \mathrm{C}$, respectively.

At the Stubai site, the meadow is typically cut for haying once a year at the end of July, manured every 2-4 yr, and has been used for light grazing by cattle in late summer since 1990 (moderate management intensity). At the Matsch site, the hay meadow is irrigated during dry summers, mowed twice a year and manured every year in autumn (high management intensity). Given continuous meadow management SOM fractions are assumed to be at steady state. With socio-economic transformations in European mountain regions meadow management was reduced and grasslands were converted to less labor-intensive pastures or left abandoned. At the Stubai site, the pasture, a former hay meadow previously managed as described above, has been grazed by young cattle from mid-June until the end of September since 1998. The abandoned grassland had previously been grazed by cattle during summer months until management stopped in 1983. At the Matsch site, the pasture, formerly used as hay meadow, has been grazed in autumn by predominantly young cattle since the 1970s. The abandoned grassland has been used for haying and occasional grazing until about $10 \mathrm{yr}$ ago. Therefore, SOM fractions of pastures and abandoned grasslands have most likely not reached new steady state yet.

Soil temperature of $0-10 \mathrm{~cm}$ depth was recorded halfhourly over a one-year period from 21 October 2008-31 October 2009 with S-TMB sensors connected to HOBO data logger (Onset Computer, Bourne, MA, USA) in grasslands at Matsch, and TCAV sensors connected to CR10X logger (Campbell Scientific) in grasslands at Stubai.

In October 2008, three (Stubai site) or two (Matsch site) paired soil cores $\left(490 \mathrm{~cm}^{3}\right.$ volume, $\left.7 \mathrm{~cm} \varnothing\right)$ were collected in each grassland type at $0-10 \mathrm{~cm}$ depth. Places of soil core collection were situated at lateral distances of 20-100 m from each other. The sampling locations were all free of shadowing-effects from trees and south-southeast facing. Inclination of all sites varied in the range of $25 \pm 3^{\circ}$.

\subsection{Physical fractionation}

Physical density fractionation of soil aims to extract homogeneous SOM fractions to derive turnover times using their radiocarbon signature. Briefly, the field-moist soil core was weighed and gently passed through a $6.3 \mathrm{~mm}$ sieve. Roots remaining on the sieve were washed and dried at $60^{\circ} \mathrm{C}$, and stones were collected. An aliquot was retrieved for moisture correction of bulk density of fine earth.

Following the aggregate and density fractionation presented in Cambardella and Elliott $(1993,1994) 100 \mathrm{~g}$ of dried soil $<6.3 \mathrm{~mm}$ was wet-sieved sequentially through $2 \mathrm{~mm}$ and $0.25 \mathrm{~mm}$ sieves allowing for slaking to occur for $10 \mathrm{~min}$ to retrieve two size classes of $2-6.3 \mathrm{~mm}$ and $0.25-2 \mathrm{~mm}$ of macroaggregates and one size class $<0.25 \mathrm{~mm}$ of microaggregates. POM floating on the water (wPOM) was collected 
Table 1. Site and soil characteristics of upper $10 \mathrm{~cm}$ of meadow, pasture and abandoned grassland at the Stubai and Matsch site.

\begin{tabular}{|c|c|c|c|}
\hline & \multicolumn{3}{|c|}{ Grassland type } \\
\hline & Meadow & Pasture & Abandoned \\
\hline \multicolumn{4}{|c|}{ Stubai } \\
\hline \multirow[t]{2}{*}{ Location (Lat./Long.) } & $47.12925^{\circ} \mathrm{N}$ & $47.12872^{\circ} \mathrm{N}$ & $47.12505^{\circ} \mathrm{N}$ \\
\hline & $11.30575^{\circ} \mathrm{E}$ & $11.30328^{\circ} \mathrm{E}$ & $11.28975^{\circ} \mathrm{E}$ \\
\hline Elevation (m a.s.1.) & 1850 & 1950 & 2000 \\
\hline Aspect & E-SE & SE & S-SE \\
\hline MAT $\left({ }^{\circ} \mathrm{C}\right)$ & $3.0^{\mathrm{a}}$ & 3.0 & 3.0 \\
\hline MAP (mm) & $1097^{\mathrm{a}}$ & 1097 & 1097 \\
\hline Start of LUC & - & 1998 & 1983 \\
\hline $\mathrm{pH}\left(\mathrm{CaCl}_{2}\right)$ & 4.9 & 5.5 & 5.4 \\
\hline Bulk density $\left(\mathrm{g} \mathrm{cm}^{-3}\right)$ & 0.7 & 0.6 & 0.5 \\
\hline Soil texture & loamy sand & sandy loam & sandy loam \\
\hline Soil type & Cambisol & Cambisol & Cambisol \\
\hline Soil temperature ${ }^{\mathrm{c}}\left({ }^{\circ} \mathrm{C}\right)$ & 6.6 & 7.3 & 6.0 \\
\hline Vegetation type & $\begin{array}{l}\text { Trisetetum } \\
\text { flavescentis }^{\mathrm{d}}\end{array}$ & $\begin{array}{l}\text { Seslerio-Caricetum } \\
\text { sempervirentis }^{\mathrm{d}}\end{array}$ & $\begin{array}{l}\text { Erico carnae } \\
\text {-Pinetum prostratae }\end{array}$ \\
\hline \multicolumn{4}{|c|}{ Matsch } \\
\hline \multirow[t]{2}{*}{ Location (Lat./Long.) } & $46.71332^{\circ} \mathrm{N}$ & $46.71356^{\circ} \mathrm{N}$ & $46.71216^{\circ} \mathrm{N}$ \\
\hline & $10.64124^{\circ} \mathrm{E}$ & $10.64070^{\circ} \mathrm{E}$ & $10.64199^{\circ} \mathrm{E}$ \\
\hline Elevation (m a.s.1.) & 1890 & 1860 & 1790 \\
\hline Aspect & SE & SE & SE \\
\hline $\operatorname{MAT}\left({ }^{\circ} \mathrm{C}\right)$ & $6.6^{\mathrm{b}}$ & 6.6 & 6.6 \\
\hline MAP (mm) & $527^{\mathrm{b}}$ & 527 & 527 \\
\hline Start of LUC & - & 1972 & 1998 \\
\hline $\mathrm{pH}\left(\mathrm{CaCl}_{2}\right)$ & 5.8 & 4.9 & 5.0 \\
\hline Bulk density $\left(\mathrm{g} \mathrm{cm}^{-3}\right)$ & 0.5 & 0.6 & 0.5 \\
\hline Soil texture & sandy loam & sandy loam & sandy loam \\
\hline Soil type & Cambisol & Cambisol & Cambisol \\
\hline Soil temperature ${ }^{\mathrm{c}}\left({ }^{\circ} \mathrm{C}\right)$ & 7.7 & 9.4 & 9.0 \\
\hline \multirow[t]{2}{*}{ Vegetation type } & Trisetetum & Sclerantho- & Trifolio montani \\
\hline & flavescentis $^{\mathrm{e}}$ & $\begin{array}{l}\text { Sempervivetum } \\
\text { arachnoidei }^{\mathrm{e}}\end{array}$ & $\begin{array}{l}\text {-Brachypodietum } \\
\text { rupestris }\end{array}$ \\
\hline
\end{tabular}

weather data from nearest weather station located at

a 1750 m.a.s.l. at Stubai Valley and

b $1570 \mathrm{~m}$ a.s.l. at Matsch Valley

c 2008-2009

d from Rubatscher (2008)

e G. Niedrist, personal communication, 2009, European Academy of Bolzano (EURAC), Italy

and used for $\mathrm{C}$ and isotope analysis as this distinct litter fraction is typical for mountain soils (Leifeld et al., 2009; Neff et al., 2009). All samples were dried at $60^{\circ} \mathrm{C}$. Stones $>2 \mathrm{~mm}$ were collected and used together with the mass of stones $>6.3 \mathrm{~mm}$ and roots to correct bulk density calculations taking into account a density of $2.65 \mathrm{~g} \mathrm{~cm}^{-3}$ of the parent material. A 5-15 g subsample of each aggregate size was suspended in centrifuge glasses using $70 \mathrm{ml}$ of $1.6 \mathrm{~g} \mathrm{~cm}^{-3}$ sodium polytungstate. Floating fPOM was separated after two replicated centrifugation steps with stirring in between, washed with deionized water (to reach electrical conductivity of $<0.5 \mathrm{~S} \mathrm{~cm}^{-1}$ ), and then dried at $60^{\circ} \mathrm{C}$. The same procedure was repeated after ultrasonication with a calibrated ultrasonic probe-type (Bandelin, Berlin, Germany) and an output energy of $22.5 \mathrm{~J} \mathrm{ml}^{-1}$ to release oPOM from every aggregates size class. Mass balance showed that on average more than $98 \%$ of the material, three aggregate size classes and wPOM, was recovered after wet sieving and $\mathrm{C}$ balance calculations revealed losses or gains of $-5 \%$ to $+8 \%$ and $-9 \%$ to $+15 \%$ for samples from the Stubai and Match site, respectively. We define wPOM and fPOM as free and oPOM and $\mathrm{mOM}\left(>1.6 \mathrm{~g} \mathrm{~cm}^{-3}\right)$ as protected within the soil matrix. Details on the distribution of water-stable aggregates and aggregate-associated C appear in Meyer et al. (2012). 
Table 2. C stocks, ${ }^{14} \mathrm{C}$ concentrations for roots, SOM fractions and bulk SOM of meadow, pasture and abandoned grassland at the Stubai and Matsch site. For $\mathrm{C}$ stocks mean and standard error of $4-6$ replicates is shown. The AMS precision $(1 \sigma)$ for ${ }^{14} \mathrm{C}$ concentrations is \pm 0.4 pMC.

\begin{tabular}{|c|c|c|c|c|c|c|}
\hline & \multicolumn{3}{|c|}{$\mathrm{C}$ stock $\left(\mathrm{kg} \mathrm{C} \mathrm{m}^{-2}\right)$} & \multicolumn{3}{|c|}{${ }^{14} \mathrm{C}$ concentration $(\mathrm{pMC})$} \\
\hline & Meadow & Pasture & Abandoned & Meadow & Pasture & Abandoned \\
\hline \multicolumn{7}{|c|}{ Stubai } \\
\hline roots & $0.28 \pm 0.02$ & $0.16 \pm 0.01$ & $0.39 \pm 0.04$ & 105.9 & 105.3 & 106.1 \\
\hline wPOM & $0.08 \pm 0.02$ & $0.11 \pm 0.02$ & $0.83 \pm 0.28$ & 107.7 & 106.3 & 107.3 \\
\hline fPOM & $0.30 \pm 0.04$ & $0.27 \pm 0.02$ & $1.25 \pm 0.44$ & 105.8 & 104.1 & 106.6 \\
\hline oPOM & $0.32 \pm 0.04$ & $0.36 \pm 0.05$ & $0.42 \pm 0.06$ & 106.6 & 105.7 & 108.1 \\
\hline $\mathrm{mOM}$ & $2.78 \pm 0.36$ & $3.21 \pm 0.17$ & $2.29 \pm 0.09$ & 103.6 & 102.7 & 103.4 \\
\hline SOM & $3.45 \pm 0.41$ & $3.96 \pm 0.24$ & $4.79 \pm 0.59$ & 104.2 & 103.5 & 104.9 \\
\hline \multicolumn{7}{|c|}{ Matsch } \\
\hline roots & $0.12 \pm 0.01$ & $0.28 \pm 0.03$ & $0.30 \pm 0.11$ & 104.7 & 106.1 & 106.0 \\
\hline wPOM & $0.17 \pm 0.06$ & $0.56 \pm 0.09$ & $0.31 \pm 0.04$ & 105.2 & 108.9 & 108.4 \\
\hline fPOM & $0.37 \pm 0.05$ & $0.57 \pm 0.04$ & $0.54 \pm 0.05$ & 106.4 & 106.6 & 109.1 \\
\hline oPOM & $0.55 \pm 0.05$ & $0.37 \pm 0.02$ & $0.46 \pm 0.04$ & 109.6 & 108.5 & 110.6 \\
\hline $\mathrm{mOM}$ & $3.22 \pm 0.10$ & $3.16 \pm 0.15$ & $3.15 \pm 0.31$ & 105.4 & 104.4 & 103.9 \\
\hline SOM & $4.32 \pm 0.10$ & $4.66 \pm 0.24$ & $4.46 \pm 0.32$ & 106.1 & 105.1 & 105.3 \\
\hline
\end{tabular}

\subsection{Total SOM-C and Isotope Analysis}

Samples were carbonate-free, and hence SOM-C was similar to total C. Total C was measured on bulk soils samples, POM fractions and roots by dry combustion in an elemental analyser (Euro EA, Hekatech, Wegberg, Germany) at Agroscope, Zürich, Switzerland. Bulk soil material, POM, and roots were combusted and graphitised for AMS measurements of radiocarbon content. ${ }^{14} \mathrm{C}$ concentrations refer to composite samples for each grassland type. This yielded in one bulk soil, wPOM and root sample, and one PPOM and oPOM fraction for each meadow, pasture and abandoned grassland at both sites. Samples were measured at the Accelerator Mass Spectrometry (AMS) facility at the ETH Zürich, Switzerland. The results were expressed as percent Modern Carbon (pMC), calculated following the protocol of Stuiver and Polach (1977) $\left(\mathrm{pMC}_{\mathrm{atm}}=\Delta^{14} \mathrm{C}_{\mathrm{atm}} / 1000+1\right) . \Delta \Delta^{14} \mathrm{C}$ is a special nomenclature introduced for bomb radiocarbon that reports ${ }^{14} \mathrm{C} /{ }^{12} \mathrm{C}$ ratios in relation to an absolute standard that does not change with time and is corrected for decay between the year of measurement and 1950 (Stuiver and Polach, 1977). Carbon content and isotope ratios of mOM were calculated by difference to bulk soil.

\subsection{Modeling SOM-C dynamic with bomb radiocarbon}

For SOM in C balance, losses from biological activity are balanced by organic inputs from plants, when $\mathrm{C}$ losses through leaching or erosion are neglected. Ecosystem disturbances, such as human-induced changes in land-use have the potential to disrupt this balance (Paterson et al., 2009). SOM fractions that have accumulated $\mathrm{C}$ during the past $30 \mathrm{yr}$ will contain more bomb radiocarbon than those that have remained at steady state.

Modeling $\mathrm{C}$ input $(I)$ and decomposition $(k)$ rates using radiocarbon measurements requires the record of ${ }^{14} \mathrm{C}$ in atmospheric $\mathrm{CO}_{2}$ incorporated by plants. We used the ${ }^{14} \mathrm{C}$ record in atmospheric $\mathrm{CO}_{2}$ for the Northern Hemisphere from Stuiver et al. (1998) until 1954 and from Levin and Kromer (2004) for the time periods 1959-1983 and 19872008 (I. Levin, personal communication, 2004-2008). For the latter period values of Jungfraujoch (3000 $\mathrm{m}$ a.s.l.) and Schauinsland (1200 $\mathrm{m}$ a.s.l.) were averaged in order to gain appropriate results for the subalpine grassland sites at $1900 \mathrm{~m}$ a.s.1.. Periods between 1955-1958 and 1984-1986 were linearly interpolated. Atmospheric ${ }^{14} \mathrm{C}$ contents in 1974-1975 were taken from Levin et al. (1994). We used two approaches to model the evolution of $\Delta{ }^{14} \mathrm{C}$ :

\section{Steady-state model}

For SOM fractions whose $\mathrm{C}$ stock did not change along the land-use gradient (all fractions of both meadows and the pasture at Stubai site; oPOM-C and mOM-C of all grasslands) (Table 2) and root-C with turnover in the range of $<5 \mathrm{yr}$ we used a steady-state model as presented in Torn et al. (2009)

$\mathrm{pMC}_{\mathrm{SOM}}(t)=k \times \mathrm{pMC}_{\mathrm{atm}}\left(t-t_{l}\right)+\mathrm{pMC}_{\mathrm{SOM}}(t-1) \times(1-k-\lambda)$,

where $\mathrm{pMC}_{\mathrm{SOM}}(t)$ represents the steady-state reservoir of SOM-C in year $t, k$ is the decomposition rate $\left(\mathrm{yr}^{-1}\right)$, $\mathrm{pMC}_{\mathrm{atm}}\left(t-t_{l}\right)$ is the ${ }^{14} \mathrm{C}$ concentration in the atmosphere $\left(\mathrm{pMC}_{\mathrm{atm}}\left(t-t_{l}\right)=\Delta^{14} \mathrm{C}_{\mathrm{atm}}\left(t-t_{l}\right) / 1000+1\right)$ in year $\left(t-t_{l}\right)$, 
where $t_{l}$ represents the time lag between photosynthetic fixation and addition to SOM (Fig. 1a), and $\lambda$ is the radioactive decay constant for ${ }^{14} \mathrm{C}$, equal to $1 / 8267 \mathrm{yr}$. The decomposition rate $k$ is adjusted to match ${ }^{14} \mathrm{C}$ concentrations of SOM fractions in the year of measurement (2008). The AMS precision $( \pm 1 \sigma)$ is $\pm 0.4 \mathrm{pMC}$. This error was used in calculations of variation in $\mathrm{C}$ decomposition and accumulation rates.

Since the $\mathrm{C}$ stock is at steady state: $I=C(t) \times k$. I is the annual $\mathrm{C}$ input rate to SOM fractions in $\mathrm{kg} \mathrm{C} \mathrm{m}^{-2} \mathrm{yr}^{-1}$ and $\mathrm{C}$ is the measured $\mathrm{C}$ stock in $\mathrm{kg} \mathrm{C} \mathrm{m}^{-2}$ in the year of sampling 2008. For fPOM, oPOM and mOM fractions we added a time lag that was equal to the turnover time of roots (1-4 yr) of the respective grassland type. For the litter fraction (wPOM) we assumed that annual $\mathrm{C}$ additions are labeled with the ${ }^{14} \mathrm{C}$ of the same years atmosphere as litter falls on the soil surface after senescence (zero $t_{l}$ ).

\section{C accumulation model}

For SOM fractions that have accumulated $\mathrm{C}$ since reduction of management intensity (wPOM and FPOM of the pasture at Matsch site and both abandoned grasslands) (Table 2) we estimated changes in $\mathrm{C}$ storage and flux since LUC using an accumulation model (modified after Gaudinski et al. (2000) and Schulze et al. (2009)). We assumed that C accumulation started in the year of LUC $\left(t_{i}=1972,1983,1998\right)$ and that SOM-C $(\mathrm{C}(t))$ in $\mathrm{kg} \mathrm{C} \mathrm{m}^{-2}$ in every year $t$ is the sum of the existing decomposing $\mathrm{C}$ stock $C\left(t_{i}-1\right)$ and the new $\mathrm{C}$ input $I$ accumulating at a certain rate (Eq. 2). $C\left(t_{i}-1\right)$ was equal to the measured steady-state SOM-C stock in 2008 of the respective grassland before LUC. The radiocarbon content of the initially existing SOM-C fraction before LUC pMC SOM $\left(t_{i}-1\right)$ was taken from the steady-state model. Equation (3) expresses the mass-weighted radiocarbon content of a SOM fraction after initiation of $\mathrm{C}$ accumulation following LUC:

$$
\mathrm{C}(t)=\mathrm{C}\left(t_{i}-1\right) \times e^{-k\left(t-t_{i}-1\right)}+\sum_{t^{\prime}=t_{i}}^{t}\left(I \times e^{-k\left(t-t^{\prime}\right)}\right),
$$

$$
\begin{aligned}
& \mathrm{pMC}_{\mathrm{SOM}}(t)= \\
& \frac{\mathrm{C}\left(t_{i}-1\right) \times \mathrm{pMC}_{\mathrm{SOM}}\left(t_{i}-1\right) \times e^{-k\left(t-t_{i}-1\right)}+\sum_{t^{\prime}=t_{i}}^{t}\left(I \times \mathrm{pMC}_{\mathrm{atm}}\left(t-t_{l}\right) \times e^{-k\left(t-t^{\prime}\right)}\right)}{\mathrm{C}(t)}
\end{aligned}
$$

Since the $\mathrm{C}$ stock is not at steady state $(I \neq \mathrm{C}(t) \times k)$ both $I$ and $k$, which are assumed to be constant, were adjusted to match $\mathrm{C}$ stock and $\mathrm{pMC}$ value for the specific SOM fractions in 2008, listed in Table 2. The annual change in $\mathrm{C}$ was developed based on the relative (\%) change in SOM-C with respect to the initial $\mathrm{C}$ stock before $\mathrm{LUC}$ in order to reflect the temporal change in $\mathrm{C}$ accumulation. Therefore, we added a time frame until 2030 to gain information about the potential of grassland abandonment to sequester $\mathrm{C}$ in the short or longer run. We explicitly assumed that ecosystem conditions remain constant within the next $20 \mathrm{yr}$. The rate of accumulation of $\mathrm{C}$ in $\mathrm{g} \mathrm{C} \mathrm{m}^{-2} \mathrm{yr}^{-1}$ for a SOM fraction in 2008 is the difference in calculated C stock between 2007 and 2008.

Tracking the atmospheric record of ${ }^{14} \mathrm{CO}_{2}$ of the last century it is comprehensive that under steady-state conditions bomb radiocarbon models produce two different turnover times that may yield to the same $\Delta^{14} \mathrm{C}$ value, if $\mathrm{pMC}_{\mathrm{SOM}}(2008)>\mathrm{pMC}_{\mathrm{atm}}(2008)$. Consequently, in $\mathrm{C}$ accumulation models that started accumulation after the bomb spike in 1963, there is only one turnover that yields in both measured $\Delta^{14} \mathrm{C}$ and $\mathrm{C}$ content of the SOM fraction. However, $\mathrm{C}$ accumulation can be modeled from two turnover times for the initial $\mathrm{C}$ stock at steady state, which also leads to two solutions for the $\mathrm{C}$ accumulation model. The difference between the two solutions is dependent on the extent of $\mathrm{C}$ accumulation (Fig. 1b).

Regarding the choice of appropriate turnover, roots and litter are very unlikely to have turnover $>100 \mathrm{yr}$ and thus we assumed a turnover in the range of $<10 \mathrm{yr}$ for both root-C and wPOM-C. Results from SOM studies in different grassland systems suggest that f- and oPOM are functionally different pools within the soil matrix responding differently to changes in management intensity (Steffens et al., 2009, 2011). In meadows the amount of assimilating plant matter is reduced but with cessation of cutting litter availability increases and fPOM accumulates, while protected oPOM remains generally unaffected by this undisturbed LUC. Therefore, we explicitly assumed that in meadows both POM fractions have low $\mathrm{C}$ input rates and turnover, but with time and LUC C input rates to fPOM increase. This assumption is corroborated by the lack a fast turnover solution for the fPOM-C in the meadow at Stubai. The mOM-C had lower ${ }^{14} \mathrm{C}$ concentrations than all three POM fractions and 104.6 pMC, the atmospheric ${ }^{14} \mathrm{C}$ concentration in 2008 for the used record, but the exception of the meadow at Matsch. This pattern indicates a slower turnover compared with roots or POM fractions exhibiting ${ }^{14} \mathrm{C}$ concentrations within the atmospheric bomb ${ }^{14} \mathrm{C}$ window between 1953 and today.

\subsection{Statistics}

Unavoidable pseudo-replication in sampling did not permit to use a One-Way ANOVA to comprehend changes in $\mathrm{C}$ stocks, input and decomposition rates along the land-use gradients. For this reason, we followed the suggestion of Hurlbert (1984) and Webster (2001) and interpreted the results based on means and standard errors $(1 \mathrm{SE}= \pm)$.

\section{Results}

\subsection{Soil C stocks}

Table 2 summarizes measured $\mathrm{C}$ stocks in $\mathrm{kg} \mathrm{C} \mathrm{m}^{-2}$ for the year 2008 of SOM fractions in upper $0-10 \mathrm{~cm}$ of three grassland soils of different management intensity. Highest bulk 
SOM-C stocks were measured in abandoned grassland at Stubai and pasture at Matsch. Among SOM-C the wPOM$\mathrm{C}$ and $\mathrm{fPOM}-\mathrm{C}$ stocks were most affected and increased after respective LUC. The proportion of POM-C in SOM$\mathrm{C}$ ranged from $11-43 \%$ in pastures and abandoned grasslands at both sites. The oPOM and mOM showed only slight $\left(<0.10 \mathrm{~kg} \mathrm{C} \mathrm{m}^{-2}\right)$ or no accumulation of $\mathrm{C}$ towards abandonment. At Stubai C stocks did not vary among SOM fractions between meadow and pasture, but w- and fPOM-C stocks increased by 0.72 and $0.98 \mathrm{~kg} \mathrm{C} \mathrm{m}^{-2}$ when comparing pasture to abandoned grassland. At Matsch wPOM-C and fPOM-C stocks increased from meadow to pasture and from meadow to abandoned grassland, while differences between pasture and abandoned grassland were small. The oPOM-C and mOM-C stocks were highest in meadow. The $\mathrm{C}$ stocks of oPOM-C and mOM-C were higher in all grasslands at Matsch than at Stubai. In all grasslands the major part of SOM-C was mineral-associated. In both managed grasslands the proportion of mOM-C in SOM-C was lower at Matsch than at Stubai.

\subsection{Soil C input and decomposition rates}

Tables 3 and 4 compare bomb radiocarbon-derived $\mathrm{C}$ input rates in $\mathrm{g} \mathrm{C} \mathrm{m}^{-2} \mathrm{yr}^{-1}$ and decomposition rates in $\mathrm{yr}^{-1}$ necessary to maintain both steady-state and nonsteady-state $\mathrm{C}$ stocks in 2008. In 2008 the $\mathrm{C}$ input to bulk SOM ranged from $101.8-578.8 \mathrm{~g} \mathrm{C} \mathrm{m}^{-2} \mathrm{yr}^{-1}$ at Stubai and from 190.6$247.1 \mathrm{~g} \mathrm{C} \mathrm{m}^{-2} \mathrm{yr}^{-1}$ at Matsch. Highest $\mathrm{C}$ input rates were estimated for the abandoned grassland at Stubai and for the intensively managed meadow at Matsch. Because decomposition rates in nonsteady-state systems do not reflect the mean residence time of $\mathrm{C}$ atoms in certain organic matter stocks, it was not reasonable to calculate the weighted mean decomposition rate for bulk SOM-C. Decomposition rates decreased from POM-C to mOM-C across grasslands at both sites. In all subalpine grasslands, $\mathrm{C}$ turnover ranged from years to decades and, on average, increased from roots $(3 \mathrm{yr})$ $<\operatorname{wPOM}(5 \mathrm{yr})<$ fPOM $(80 \mathrm{yr})<$ oPOM $(108 \mathrm{yr})<$ mOM (192 yr). This trend was consistent with results from Swanston et al. (2005); Liao et al. (2006) and Budge et al. (2011), who also calculated shorter turnover times for free POM as opposed to aggregate- or mineral-associated SOM. However, the fPOM-C turnover varied most in response to grassland management and among grasslands turnover ranged from 3-184 yr at Stubai and from 6-132 yr at Matsch. $I$ and $k$ of oPOM and $\mathrm{mOM}$ in all grasslands were higher at Matsch than at Stubai. For example, the mOM-C turned over in the range of 200-250 yr at Stubai and 142-200 yr at Matsch and received on average $6.9 \mathrm{~g} \mathrm{C} \mathrm{m}^{-2}$ more $\mathrm{C}$ input. Compared with w- and fPOM-C input and decomposition rates of oPOM-C and mOM-C were relatively balanced following management change. Based on these results we consider free w- and PPOM-C as labile and both protected oPOM-C and mOM-C as stable SOM-C.
The wPOM and FPOM of pasture at Matsch and both abandoned grasslands accumulated $\mathrm{C}$ since LUC and the two unique parameters describing soil $\mathrm{C}$ flux, $I$ and $k$, were calculated from the nonsteady-state model (Eqs. 2 and 3). Because of large changes in atmospheric ${ }^{14} \mathrm{C}$ content since the late 1950s, the input rates for radiocarbon differs from the constant input rate assumed for SOM at steady state. Therefore, it is important to note that decomposition and input rates of wPOM-C and PPOM-C in pasture at Matsch and abandoned grasslands at both sites represent SOM that has accumulated $\mathrm{C}$ for different periods of time. At Stubai C input rates of wPOM increased with abandonment. In the abandoned grassland $\mathrm{C}$ input was 12 and 5 times higher than in meadow and pasture, respectively. Together with only slight changes in decomposition rates the higher $\mathrm{C}$ input is responsible for the increase in wPOM-C stocks towards abandonment. Carbon inputs to wPOM, the litter component, increased from 11.4 to $133.9 \mathrm{~g} \mathrm{C} \mathrm{m}^{-2} \mathrm{yr}^{-1}$ at Stubai and decreased from 72.2 to $63.4 \mathrm{~g} \mathrm{C} \mathrm{m}^{-2} \mathrm{yr}^{-1}$ at Matsch. Input rates are in the range of measurements from Hitz et al. (2001) who observed an annual aboveground $C$ input of 17.9 to $60.2 \mathrm{~g} \mathrm{C} \mathrm{m}^{-2} \mathrm{yr}^{-1}$ to subalpine and alpine grasslands in the Swiss Alps. Also, the increase in PPOM-C stock towards abandonment is related to higher $\mathrm{C}$ input rates compensating for higher decomposition rates. Carbon input increased from 1.5 to $339.2 \mathrm{~g} \mathrm{C} \mathrm{m}^{-2} \mathrm{yr}^{-1}$ to account for an increase in $\mathrm{C}$ stock of $980 \mathrm{~g} \mathrm{C} \mathrm{m}^{-2}$ from pasture to abandoned grassland at Stubai. The sharp increase has several reasons. First, among SOM the increase in $\mathrm{C}$ was highest for fPOM, which means that this fraction is most affected by LUC. Second, assuming a $3 \mathrm{yr}$ time lag there was no solution to Eq. (3) for a fast $\mathrm{C}$ turnover of fPOM. Third, results for 2008 represent a snapshot in time on the way to a new steady state and the $\mathrm{C}$ change rate is likely to decrease with time (Conant et al., 2001). Fourth, plant residues do neither have a single nor constant decomposition rate. With a sudden increase in aboveground plant matter after cessation of mowing and grazing the estimated decomposition rate $k$ might reflect the initial rapid breakdown of labile compounds. Consequently, cumulated total soil $\mathrm{C}$ input of $578.8 \mathrm{~g} \mathrm{C} \mathrm{m}^{-2} \mathrm{yr}^{-1}$ of the abandoned grassland, is high compared to grassland soils at steady state.

At the Matsch site $\mathrm{C}$ input rates of wPOM, roots, oPOM and $\mathrm{mOM}$ was highest in the intensively managed meadow compared to pasture and abandoned grassland. Meadow management also affected decomposition rates of root and wPOM-C, which in both cases were 3 and 2 times that of pasture and abandoned grassland, respectively. Decomposition rates were highest for fPOM-C in pasture, but high $\mathrm{C}$ input compensated the higher $\mathrm{C}$ efflux and led to an accumulation of $0.20 \mathrm{~kg} \mathrm{C} \mathrm{m}^{-2}$ within $36 \mathrm{yr}$ of LUC. In meadows, all SOM fractions had slower decomposition rates in the moderately managed meadow at Stubai site, with differences being most pronounced for roots and wPOM-C. For pastures $\mathrm{C}$ inputs to all SOM-C fractions were lower at Stubai, while there was 
Table 3. Input rates $I$ for roots, SOM fractions, total soil (roots+SOM) and contribution of roots to soil C input of meadow, pasture and abandoned grassland at the Stubai and Matsch site. I was calculated based on the radiocarbon signature using steady-state and nonsteadystate models (*). Both models produce two solutions yielding in the measured radiocarbon content and C stock in 2008. Implausible solutions are put in parenthesis. For the definition of implausible solutions see methods.

\begin{tabular}{|c|c|c|c|c|c|c|}
\hline \multirow[b]{3}{*}{ roots } & \multicolumn{6}{|c|}{ Input rate $\left(\mathrm{g} \mathrm{C} \mathrm{m}^{-2} \mathrm{yr}^{-1}\right)$} \\
\hline & \multicolumn{2}{|c|}{ Meadow } & \multicolumn{2}{|c|}{ Pasture } & \multicolumn{2}{|c|}{ Abandoned } \\
\hline & $71.8 \pm 13.3$ & $(2.0 \pm 0.1)$ & $\begin{array}{l}\text { Stubai } \\
63.1 \pm 23.6\end{array}$ & $(1.1 \pm<0.1)$ & $90.6 \pm 15.2$ & $(2.9 \pm 0.2)$ \\
\hline wPOM & $11.4 \pm 0.9$ & $(0.7 \pm<0.1)$ & $25.4 \pm 4.1$ & $(0.9 \pm 0.1)$ & $133.9 \pm 27.5^{*}$ & $(112.2 \pm 12.1)^{*}$ \\
\hline fPOM & - & $2.1 \pm 0.1$ & - & $1.5 \pm 0.1$ & - & $339.2 \pm 100.4^{*}$ \\
\hline oPOM & $(183.7 \pm 79.1)$ & $2.5 \pm 0.1$ & $(359.7 \pm 74.1)$ & $2.5 \pm 0.1$ & $(102.2 \pm 13.8)$ & $4.0 \pm 0.2$ \\
\hline $\mathrm{mOM}$ & - & $14.0 \pm 0.9$ & - & $14.1 \pm 1.0$ & - & $11.1 \pm 0.7$ \\
\hline total soil & \multicolumn{2}{|c|}{$101.8 \pm 15.3$} & \multicolumn{2}{|c|}{$106.6 \pm 28.9$} & \multicolumn{2}{|c|}{$578.8 \pm 144.0$} \\
\hline roots/total soil (\%) & \multicolumn{2}{|c|}{71} & \multicolumn{2}{|c|}{59} & \multicolumn{2}{|c|}{16} \\
\hline roots & $144.4 \pm 30.9$ & $(0.7 \pm<0.1)$ & $\begin{array}{l}\text { Matsch } \\
69.4 \pm 5.1\end{array}$ & $(2.1 \pm 0.1)$ & $75.2 \pm 13.6$ & $(2.2 \pm 0.1)$ \\
\hline wPOM & $72.2 \pm 27.1$ & $(1.1 \pm 0.1)$ & $64.8 \pm 4.3^{*}$ & $(37.2 \pm 2.5)^{*}$ & $63.4 \pm 3.4^{*}$ & $(21.7 \pm 1.7)^{*}$ \\
\hline fPOM & $(96.0 \pm 17.8)$ & $2.8 \pm 0.2$ & $(341.3 \pm 146.9)^{*}$ & $45.4 \pm 10.8 *$ & $(134.5 \pm 10.0)^{*}$ & $29.6 \pm 3.1^{*}$ \\
\hline oPOM & $(64.4 \pm 3.4)$ & $6.3 \pm 0.3$ & $(78.3 \pm 4.1)$ & $3.6 \pm 0.2$ & $(60.9 \pm 3.3)$ & $5.8 \pm 0.3$ \\
\hline $\mathrm{mOM}$ & $(1695.7 \pm 1035.6)$ & $21.4 \pm 1.2$ & - & $18.0 \pm 1.1$ & - & $16.6 \pm 1.0$ \\
\hline total soil & \multicolumn{2}{|c|}{$247.1 \pm 59.7$} & \multicolumn{2}{|c|}{$201.2 \pm 21.5$} & \multicolumn{2}{|c|}{$190.6 \pm 21.4$} \\
\hline roots/total soil (\%) & \multicolumn{2}{|c|}{58} & \multicolumn{2}{|c|}{35} & \multicolumn{2}{|c|}{39} \\
\hline
\end{tabular}

Table 4. Decomposition $k$ rates of roots and SOM fractions of meadow, pasture and abandoned grassland at the Stubai and Matsch site. $k$ was calculated based on the radiocarbon signature using steady-state and nonsteady-state models $\left(^{*}\right)$. Both models produce two solutions yielding in the measured radiocarbon content and $\mathrm{C}$ stock in 2008. Implausible solutions are put in parenthesis. For the definition of implausible solutions see methods.

\begin{tabular}{|c|c|c|c|c|c|c|}
\hline \multirow[b]{4}{*}{ roots } & \multicolumn{6}{|c|}{ Decomposition rate $\left(\mathrm{yr}^{-1}\right)$} \\
\hline & \multicolumn{2}{|c|}{ Meadow } & \multicolumn{2}{|c|}{ Pasture } & \multicolumn{2}{|c|}{ Abandoned } \\
\hline & & & Stubai & & & \\
\hline & $0.256 \pm 0.048$ & $(0.007 \pm 0.0004)$ & $0.392 \pm 0.147$ & $(0.007 \pm 0.0004)$ & $0.233 \pm 0.039$ & $(0.007 \pm 0.0004)$ \\
\hline wPOM & $0.146 \pm 0.012$ & $(0.009 \pm 0.0005)$ & $0.222 \pm 0.035$ & $(0.007 \pm 0.0004)$ & $0.174 \pm 0.020^{*}$ & $(0.162 \pm 0.020)^{*}$ \\
\hline fPOM & - & $0.007 \pm 0.0004$ & - & $0.005 \pm 0.0003$ & - & $0.406 \pm 0.156^{*}$ \\
\hline oPOM & $(0.571 \pm 0.246)$ & $0.008 \pm 0.0004$ & $(1.000 \pm 0.206)$ & $0.007 \pm 0.0004$ & $(0.241 \pm 0.033)$ & $0.009 \pm 0.0005$ \\
\hline $\mathrm{mOM}$ & - & $0.005 \pm 0.0003$ & - & $0.004 \pm 0.0003$ & - & $0.005 \pm 0.0003$ \\
\hline \multicolumn{7}{|c|}{ Matsch } \\
\hline roots & $0.833 \pm 0.179$ & $(0.006 \pm 0.0004)$ & $0.244 \pm 0.043$ & $(0.007 \pm 0.0004)$ & $0.250 \pm 0.045$ & $(0.007 \pm 0.0004)$ \\
\hline wPOM & $0.417 \pm 0.156$ & $(0.006 \pm 0.0004)$ & $0.122 \pm 0.009 *$ & $(0.088 \pm 0.007)^{*}$ & $0.203 \pm 0.017 *$ & $(0.100 \pm 0.020)^{*}$ \\
\hline fPOM & $(0.256 \pm 0.048)$ & $0.008 \pm 0.0004$ & $(0.913 \pm 0.176)^{*}$ & $0.169 \pm 0.044^{*}$ & $(0.286 \pm 0.029)^{*}$ & $0.109 \pm 0.027 *$ \\
\hline oPOM & $(0.117 \pm 0.006)$ & $0.011 \pm 0.0006$ & $(0.211 \pm 0.025)$ & $0.010 \pm 0.0005$ & $(0.133 \pm 0.007)$ & $0.013 \pm 0.0006$ \\
\hline $\mathrm{mOM}$ & $(0.526 \pm 0.321)$ & $0.007 \pm 0.0004$ & - & $0.006 \pm 0.0003$ & - & $0.005 \pm 0.0003$ \\
\hline
\end{tabular}

no clear pattern for decomposition rates. The contribution of $\mathrm{C}$ input from roots to soil decreased with abandonment.

Figure 2 captures information on relevant time periods for $\mathrm{C}$ accumulation in free POM fractions. In agreement with results on $\mathrm{C}$ accumulation from long-term studies (Buyanovsky and Wagner, 1998; Johnston et al., 2009), wPOM-C and fPOM-C stocks do not accumulate permanently. The increase in $\mathrm{C}$ stock ceases as a new steady-state value is approached (Fig. 2a, b). At both sites, most $\mathrm{C}$ is sequestered in the first years after LUC (Fig. 2c, d).
The rates of $\mathrm{C}$ accumulation, as the difference in $\mathrm{C}$ stocks calculated for 2007 and 2008, decreased with time (36, 25 and $10 \mathrm{yr}$ ) since reduction of management intensity. For wPOM-C it decreased from $7.4 \pm 1.0>2.2 \pm 1.1>0.8$ $\pm 0.2 \mathrm{~g} \mathrm{C} \mathrm{m}^{-2} \mathrm{yr}^{-1}$ and for fPOM annual $\mathrm{C}$ accumulation rates decreased from $7.3 \pm 1.6>1.3 \pm 0.1>2.0 \pm 0.2 \mathrm{~g} \mathrm{C}$ $\mathrm{m}^{-2} \mathrm{yr}^{-1}$.

While wPOM still accumulates $\mathrm{C}$ after $36 \mathrm{yr}$ of abandonment, which is the longest time period studied, fPOM ceased to accumulate $\mathrm{C}$ after $14 \mathrm{yr}$ of abandonment at Stubai and 


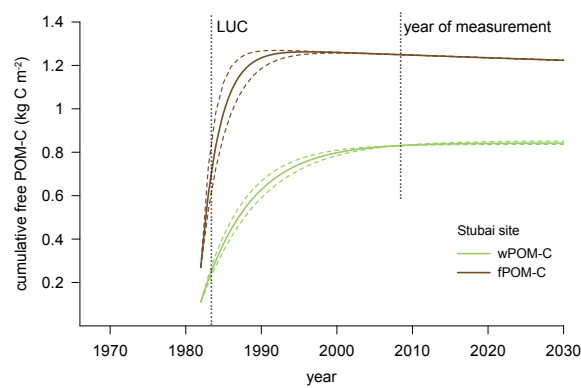

(a)

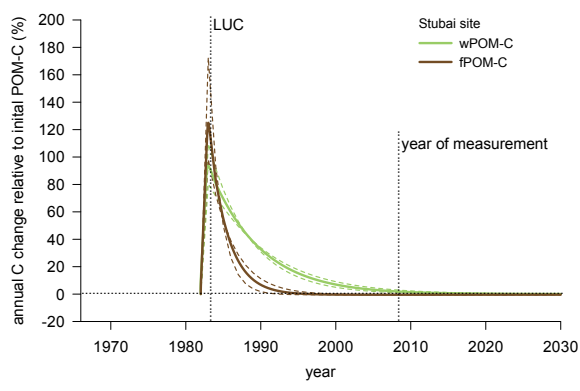

(c)

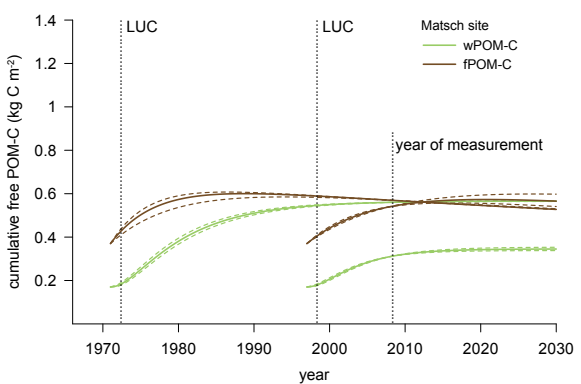

(b)

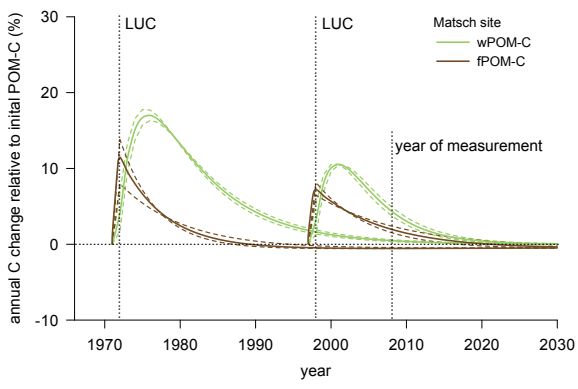

(d)

Fig. 2. Carbon (C) accumulation plot of (a) water-floatable (w-) and free (f-) particulate organic matter (POM) in nonsteady state abandoned grassland at the Stubai site from start since land-use change (LUC) in 1983 predicted until 2030 and (b) w- and fPOM-C in nonsteady state pasture and abandoned grassland at the Matsch site from start since LUC in 1972 and 1998 predicted until 2030, respectively.

Annual relative change in wPOM-C and fPOM-C since start of LUC in (c) nonsteady state abandoned grassland (1983) predicted until 2030 at the Stubai site and (d) in nonsteady state pasture (1972) and abandoned grassland (1998) predicted until 2030 at the Matsch site. C stock was measured in year 2008. Dashed lines represent $1 \sigma$ of radiocarbon measurements.

$18 \mathrm{yr}$ after change to pasture management at Matsch. Until the year 2030, fPOM-C ceases to accumulate $\mathrm{C}$ and accumulation for wPOM-C would be less than $0.1 \mathrm{~g} \mathrm{C} \mathrm{m}^{-2} \mathrm{yr}^{-1}$, assuming the same ecosystem conditions as today.

\section{Discussion}

\subsection{Effect of grassland abandonment on soil C dynamics}

We expected that a LUC related change in aboveground biomass and litter would affect POM dynamics. Comparing bomb radiocarbon-derived estimates of $\mathrm{C}$ input and decomposition rates we found differences in responsiveness to abandonment between SOM fractions. While labile SOM fractions, both w- and $\mathrm{PPOM}$, accumulated $\mathrm{C}$ with reduced management intensity there was no stabilization of $\mathrm{C}$ in protected SOM fractions. In meadow and pasture aboveground biomass is removed through cutting and grazing but is retained in abandoned grasslands. The $\mathrm{w}-$ and PPOM responded stronger to those changes than oPOM or mOM. These findings agree with results from Steffens et al. (2011), who found that with cessation of grazing a large proportion of sequestered $\mathrm{C}$ is stored in readily decomposable POM and not stabilized in the long run.

As vegetation changes and litter quality decreases with grassland abandonment, which has been assessed by $\mathrm{Ru}-$ batscher (2008) for the same land-use gradient at Stubai, we hypothesized that reduced decomposition would increase POM-C stocks. Among POM-C, only the increase in wPOM-C stocks can be related to a decrease in decomposition rates. The wPOM comprises the most undecomposed plant material among extracted SOM components and trends in litter quality are pronounced in this SOM fraction. In contrast, the increase in the fPOM-C stocks with abandonment comes along with higher decomposition rates, but a change was compensated for with higher $\mathrm{C}$ input rates. German et al. (2011) recently provided evidence that SOM decomposition is not exclusively linked to residue quality but also depends on its quantity. We assume that in grasslands the cessation of haying and grazing triggers the increase in residue quantity and availability and thus might be the prevailing factor affecting microbial activity and, in turn, decomposition rates of the more decomposed fPOM. Changes in SOM dynamics have also been linked to aggregation (Tisdall and Oades, 
1982; Golchin et al., 1994a; Six et al., 2004). The studied grassland soils were well aggregated (Meyer et al., 2012) and mechanical disturbance is small. Furthermore, the macrodecomposer activity decreases towards abandonment (Seeber et al. , 2005), which hampers the mixing between free and protected SOM.

Rasse et al. (2005) emphasized that it is essential to understand the origin of $\mathrm{C}$ in SOM to adjust management practices that will support $\mathrm{C}$ storage. Our results show that $\mathrm{C}$ input pathways to SOM in $0-10 \mathrm{~cm}$ depth change along the management gradient. Carbon input from roots to soil was highest under meadow and decreased with abandonment. Management intensity, such as organic amendments and higher cut frequency, seem to have a strong impact on productivity and allocation of $\mathrm{C}$ inputs. When fertilizer management is not sustained and cutting and grazing have been ceased, $\mathrm{C}$ inputs from roots to soil decrease whereas the proportion of litter-derived $\mathrm{C}$ increases. The intensive meadow management leads to higher $\mathrm{C}$ input rates also to oPOM and $\mathrm{mOM}$ fractions when compared to moderate management intensity despite both meadows were characterized by the same vegetation type (Table 1).

We detected site-specific differences in SOM dynamics. For stable SOM fractions we detected consistent greater biochemical cycling rates at the Matsch site, which is on average $3{ }^{\circ} \mathrm{C}$ warmer and exhibits higher soil temperatures (Table 1). The oPOM-C and mOM-C show both faster decomposition and higher input rates as well as higher $\mathrm{C}$ stocks at the warmer compared to the colder site. Soil texture is similar and does not contribute to differences in mOM-C decomposition between sites. Trumbore et al. (1996) analyzed decomposition rates along an elevation gradient and found that temperature is the dominant control for $\mathrm{C}$ dynamics, and that cooler temperatures were associated with slower decomposition. ${ }^{14} \mathrm{C}$ concentrations were also higher for the wPOM and PPOM, but as these two free POM fractions are strongly affected by a sudden increase in aboveground plant matter with abandonment, any micro-climatic interrelations might be masked. Ecosystem disturbance (Davidson and Janssens, 2006) as well as the time since LUC might obscure an intrinsic temperature sensitivity of labile POM decomposition. Our observations correspond to earlier studies in mountain regions which detected that land-use is a strong driver of ecosystem change, in particular during the first years after LUC, and its impacts may override climatic influence (Vittoz et al., 2008; Djukic et al., 2010; Schindlbacher et al., 2010). Similarly, possible effects of abandonment on oPOM or mOM may not yet be detectable considering their slow turnover in relation to the time periods studied $(10-36 \mathrm{yr}$ of LUC). The proportion of mOM-C in SOM-C ranged from $48 \%-81 \%$ and even small increases in decomposition rates in response to raised air and soil temperatures may result in a significant change in SOM in the long term (Davidson and Janssens, 2006). One possible explanation is the shift in microbial composition towards fungal biomass with abandon- ment, as shown by Zeller et al. (2000). Mycorrhizal fungi facilitate the exploitation of a greater soil volume and provide plants with additional water and nutrients.

We found that most $\mathrm{C}$ is sequestered in the first years after abandonment. Our results are consistent with findings of Conant et al. (2001) that LUC related differences in C fluxes and stocks in grasslands are high at the beginning and decrease with time. They compiled results from 115 studies including grasslands and found that $\mathrm{C}$ accumulation rates were highest during the first $40 \mathrm{yr}$. West et al. (2004) and Poeplau et al. (2011) generated carbon response functions and modeled the temporal dynamics of bulk SOM-C after pronounced LUC, i.e. from cropland to grassland or forest and vice versa. The most interesting result in relation to our study is that changes in SOM-C stock following afforestation of grasslands under temperate conditions depend on accumulated litter. Only continuous accumulation of forest litter caused an increase of SOM-C in the range of $28 \pm 11 \%$ within $100 \mathrm{yr}$ since LUC, while the change in mineral SOM-C stocks was minimal $(-7 \pm 23 \%)$ (Poeplau et al., 2011). In line with these results are empirical observations from Bitterlich et al. (1999) and Seeber and Seeber (2005) who detected a change in humus type by reduced grassland management and conversion to forest from Vermimull to Moder. The increasing difference between litter and mineral soil with grassland abandonment underlines our conclusions of limited $\mathrm{C}$ exchange between labile and stable SOM fractions.

Studies on natural ecosystem processes should be designed to reflect the reality as close as possible. In general, the space-for-time approach has been successfully used in ecological studies of secondary succession of abandoned mountain grassland when holding environmental parameters such as soil type, soil texture, climate and exposition constant (Maag et al., 2001). We are confident that we kept those parameters constant for each site within the possibilities in mountainous environments. The use of abstract models however implicates various constrains that need to be considered. Because wPOM-C fractions and fPOM-C in recently abandoned grasslands were not in steady-state between inputs and decay, we chose to include the $\mathrm{C}$ accumulation in the radiocarbon model. Thus, the initial C stock, which is based on space-for-time substitution, might become an important variable. However, when varying the initial C stock by $10-50 \%$ the $\mathrm{C}$ input to soil varied to the same magnitude as when varying the $\mathrm{pMC}$ value within the AMS precision $( \pm 1 \sigma: 0.4$ pMC). Within the time periods studied the importance of the decomposition rate of the initial $\mathrm{C}$ stock decreased with an increase in $\mathrm{C}$ accumulation (Fig. 1b). The decreasing rates of $\mathrm{C}$ accumulation with time emphasize the necessity of reliable knowledge on site history. Moreover, many studies falsely assume steady state and underestimate $\mathrm{C}$ turnover. For the wPOM fraction at Matsch, for example, $\mathrm{C}$ turnover would have been underestimated by $5 \%, 8 \%$ and $37 \%$ after 36 , 25 and $10 \mathrm{yr}$ of management reduction, respectively, when falsely assuming steady-state conditions. This illustrates the 
importance of the model choice, in particular when studying recent LUC. Furthermore, the choice of time lag is very important for fast-cycling SOM fractions and almost negligible for intermediate or slow-cycling SOM fractions as they contain only traces of bomb radiocarbon (Leifeld et al., 2009). The cumulated carbon input to total soil would decrease by $30 \%$ when neglecting the time lag of $4 \mathrm{yr}$ for the abandoned grassland soil at Stubai. This is slightly outside the AMS precision. Although the choice of time lag is a well known uncertainty in radiocarbon modeling (Trumbore, 2009), yet no better approximation exists than considering the turnover of roots in the studied systems.

\subsection{Comparison of bomb radiocarbon- and respiration-derived $\mathrm{C}$ fluxes}

The few available studies on $\mathrm{C}$ ecosystem fluxes in mountain grasslands describe $\mathrm{C}$ fluxes using eddy flux towers or chambers (Kato et al., 2004; Rogiers et al., 2005; Wohlfahrt et al., 2008a; Bahn et al., 2008; Schmitt et al., 2010). Bahn et al. (2008) measured soil respiration at the same grasslands at Stubai and derived an annual soil respiration in the range of $7.3 \mathrm{tCha}^{-1} \mathrm{yr}^{-1}$ for the pasture. Assuming a contribution of $40-50 \%$ heterotrophic respiration to SOM respiration (Hanson et al., 2000) we can derive a total C input to pasture soil in the range of $2.9-3.7 \mathrm{tC} \mathrm{ha}^{-1} \mathrm{yr}^{-1}$. Using physical fractionation and radiocarbon methods we derived an input rate of $\mathrm{C}$ to SOM of the same pasture in the order of only $1.1 \mathrm{tC} \mathrm{ha}^{-1} \mathrm{yr}^{-1}$. Our results are in the range of estimates of Leifeld and Fuhrer (2009) who radiocarbon-modeled a steady-state SOM-C input rate of 0.7 and $0.9 \mathrm{tC} \mathrm{ha}^{-1} \mathrm{yr}^{-1}$ for subalpine meadow and pasture in the Swiss Alps, respectively, and Budge et al. (2011) who derived radiocarbon-related annual $\mathrm{C}$ inputs into alpine grasslands above $2200 \mathrm{~m}$ a.s.l. in the range of 0.4 to $1.0 \mathrm{tCha}^{-1} \mathrm{yr}^{-1}$.

The discrepancy between differently derived SOM-C fluxes has several reasons. First, soil respiration and SOM-C fractionation techniques do not capture $\mathrm{C}$ fluxes of the same systems in the soil. Soil respiration measures $\mathrm{CO}_{2}$ efflux from the entire soil to the atmosphere disregarding composition and C-cycling time variation of SOM pools. Despite methodological improvements (Kuzyakov, 2006) it remains difficult to partition heterotrophic and autotrophic respiration and the latter strongly influences soil respiration measurements. This method captures predominantly the active fast-cycling dynamic pool of SOM and overestimates SOMC turnover (Torn et al., 2009). Second, both methods cover different time periods. Ecosystem flux measurements capture $\mathrm{C}$ fluxes on a daily to monthly basis. They can account for short-term effects of weather and management on the inter annual variation in $\mathrm{C}$ balance and assess $\mathrm{C}$ sink-source relations on a daily, weekly and monthly basis. (Wohlfahrt et al., 2008b; Don et al., 2009; Schmitt et al., 2010). In contrast, bomb radiocarbon signatures of SOM fractions inte- grate over annual to decadal timescales. Measurements of ${ }^{14} \mathrm{C}$ do not allow a resolution of $\mathrm{C}$ dynamic on a monthly basis, neglects fast-cycling SOM fractions and most probably underestimates soil $\mathrm{C}$ dynamics.

Despite differences in spatial and temporal resolution results of both measurement techniques reflect responses to grassland management abandonment. Schmitt et al. (2010) monitored net ecosystem exchange of $\mathrm{CO}_{2}$, gross primary productivity and ecosystem respiration rates along the same land-use gradient at the Stubai site. They found that all measures decreased with decreasing land-use intensity. For the same land-use gradient, we found an increase in soil $\mathrm{C}$ input, which is primarily attributable to the accumulation of $\mathrm{C}$ in labile POM within the first years of abandonment. As the annual change in $\mathrm{C}$ accumulation decreases with time it is essential to evaluate the year of measurement in relation to the length of time since LUC.

\section{Conclusions}

With regard to the effect of abandonment on SOM dynamics and relevant time periods for $\mathrm{C}$ accumulation we can draw two major conclusions from our results:

1. In mountain grasslands free and protected SOM fractions are ecologically distinct labile and stable SOM pools with different $C$ input pathways. While the former are strongly dependent on land-use related changes in aboveground biomass, the latter are independent of abandonment $<30 \mathrm{yr}$.

2. Our study shows that it is unlikely that the abandonment of mountain grassland, the dominant form of LUC throughout the European Alps, provides a substantial net soil C sink.

Acknowledgements. This work was funded by the Swiss Federal Office for Education and Science (C07.0031) in the framework of COST Action 639, and by the Federal Office of the Environment (09.0015.KP/I175-0721). We like to thank two anonymous reviewers for valuable comments to improve the manuscript.

Edited by: N. Ohte

\section{References}

Bahn, M., Knapp, M., Garajova, Z., Pfahringer, N., and Cernusca, A.: Root respiration in temperate mountain grasslands differing in land use, Global Change Biol., 12, 995-1006, 2006.

Bahn, M., Rodeghiero, M., Anderson-Dunn, M., Dore, S., Gimeno, C., Dröttsler, M., Williams, M., Ammann, C., Berninger, F., Flechard, C., Jones, S., Balzarolo, M., Kumar, S., Newesely, C., Priwitzer, T., Raschi, A., Siegwolf, R., Susiluoto, S., Tenhunen, J., Wohlfahrt, G., and Cernusca, A.: Soil Respiration in European Grasslands in Relation to Climate and Assimilate Supply, Ecosystems, 11, 1352-1367, 2008. 
Bitterlich, W., Pöttinger, C., Kaserer, M., Hofer, H., Aichner, M., Tappeiner, U., and Cernusca, A.: Effects of land-use changes on soils along the Eastern alpine transect, in: Land-Use Changes in European Mountain Ecosystems: ECOMONT - concepts and results, edited by: Cernusca, A., Tappeiner, U., and Bayfield, N., Blackwell Wiss.-Verl., Berlin, 1999.

Budge, K., Leifeld, J., Hiltbrunner, E., and Fuhrer, J.: Alpine grassland soils contain large proportion of labile carbon but indicate long turnover times, Biogeosciences, 8, 1911-1923, doi:10.5194/bg-8-1911-2011, 2011.

Buyanovsky, G. A. and Wagner, G. H.: Carbon cycling in cultivated land and its global significance, Global Change Biol., 4, 131141,1998

Cambardella, C. A. and Elliott, E. T.: Carbon and Nitrogen Distribution in Aggregates from Cultivated and Native Grassland Soils, Soil Sci. Soc. Am. J., 57, 1071-1076, 1993.

Cambardella, C. A. and Elliott, E. T.: Carbon and Nitrogen Dynamics of Soil Organic Matter Fractions from Cultivated Grassland Soils, Soil Sci. Soc. Am. J., 58, 123-130, 1994.

Cernusca, A., Tappeiner, U., and Bayfield, N.: Land-use Changes in European Mountain Ecosystems : ECOMONT - Concepts and Results, Blackwell Wiss.-Verl., Berlin, 1999.

Conant, R. T., Paustian, K., and Elliott, E. T.: Grassland Management and Conversion into Grassland: Effects on Soil Carbon, Ecol. Appl., 11, 343-355, 2001.

Coûteaux, M.-M., Bottner, P., and Berg, B.: Litter decomposition, climate and litter quality, Trends Ecol. Evol., 10, 63-66, 1995.

Davidson, E. A. and Janssens, I. A.: Temperature sensitivity of soil carbon decomposition and feedbacks to climate change, Nature, 440, 165-173, 2006.

Djukic, I., Zehetner, F., Tatzber, M., and Gerzabek, M. H.: Soil organic-matter stocks and characteristics along an Alpine elevation gradient, J. Plant Nutr. Soil Sci., 173, 30-38, 2010.

Don, A., Rebmann, C., Kolle, O., Scherer-Lorenzen, M., and Schulze, E.-D.: Impact of afforestation-associated management changes on the carbon balance of grassland, Global Change Biol., 15, 1990-2002, 2009.

Gamper, S., Tasser, E., and Tappeiner, U.: Short-time effects of land-use changes on O-horizon in subalpine grasslands, Plant Soil, 299, 101-115, 2007.

Gaudinski, J. B., Trumbore, S. E., Davidson, E. A., and Zheng, S.: Soil carbon cycling in a temperate forest: radiocarbon-based estimates of residence times, sequestration rates and partitioning of fluxes, Biogeochemistry, 51, 33-69, 2000.

German, D. P., Chacon, S. S., and Allison, S. D.: Substrate concentration and enzyme allocation can affect rates of microbial decomposition, Ecology, 92, 1471-1480, 2011.

Golchin, A., Oades, J. M., Skjemstad, J. O., and Clarke, P.: Soil structure and carbon cycling, Aust. J. Soil Res., 32, 1043-1068, 1994a.

Golchin, A., Oades, J. M., Skjemstad, J. O., and Clarke, P.: Study of free and occluded particulate organic matter in soils by solid state ${ }^{13} \mathrm{C}$ Cp/MAS NMR spectroscopy and scanning electron microscopy, Aust. J. Soil Res., 32, 285-309, 1994b.

Hanson, P. J., Edwards, N. T., Garten, C. T., Andrews, J. A.: Separating root and soil microbial contributions to soil respiration: A review of methods and observations, Biogeochemistry, 48, 115146, 2000.

Hitz, C., Egli, M., and Fitze, P.: Below-ground and above-ground production of vegetational organic matter along a climosequence in alpine grasslands, J. Plant Nutr. Soil Sci., 164, 389-397, 2001.

Hurlbert, S. H.: Pseudoreplication and the Design of Ecological Field Experiments, Ecol. Monogr., 54, 187-211, 1984.

Johnston, A. E., Poulton, P. R., and Coleman, K.: Soil Organic Matter: Its Importance in Sustainable Agriculture and Carbon Dioxide Fluxes, Adv. Agron., 101, 1-57, 2009.

Kato, T., Tang, Y., Gu, S., Hirota, M., Cui, X., Du, M., Li, Y., Zhao, $\mathrm{X}$., and Oikawa, T.: Seasonal patterns of gross primary production and ecosystem respiration in an alpine meadow ecosystem on the Qinghai-Tibetan Plateau, J. Geophys. Res., 109, D12109, doi:10.1029/2003JD003951, 2004.

Kuzyakov, Y.: Sources of $\mathrm{CO}_{2}$ efflux from soil and review of partitioning methods, Soil Biol. Biochem., 38, 425-448, 2006.

Leifeld, J. and Fuhrer, J.: Long-term management effects on soil organic matter in two cold, high-elevation grasslands: clues from fractionation and radiocarbon dating, Eur. J. Soil Sci., 60, 230 239, 2009.

Leifeld, J., Zimmermann, M., Fuhrer, J., and Conen, F.: Storage and turnover of carbon in grassland soils along an elevation gradient in the Swiss Alps, Global Change Biol., 15, 668-679, 2009.

Levin, I. and Kromer, B.: The tropospheric ${ }^{14} \mathrm{CO}_{2}$ level in midlatitudes of the Northern Hemisphere (1959-2003), Radiocarbon, 46, 1261-1272, 2004.

Levin, I., Kromer, B., Schoch-Fischer, H., Bruns, M., Münnich, M., Berdau, D., Vogel, J., and Münnich, K.: $\delta^{14} \mathrm{CO}_{2}$ record from Vermunt, in: Trends: A Compendium of Data on Global Change, Carbon Dioxide Information Analysis Center, Oak Ridge National Laboratory, US Department of Energy, Oak Ridge, Tenn., USA, 1994.

Liao, J. D., Boutton, T. W., and Jastrow, J. D.: Organic matter turnover in soil physical fractions following woody plant invasion of grassland: Evidence from natural ${ }^{13} \mathrm{C}$ and ${ }^{15} \mathrm{~N}$, Soil Biol. Biochem., 38, 3197-3210, 2006.

Maag, S., Nösberger, J., and Lüscher, A.: Mögliche Folgen einer Bewirtschaftungsaufgabe von Wiesen und Weiden im Berggebiet, Ergebnisse des Komponentenprojektes D, Polyprojekt PRIMALP, ETHZ, doi:10.3929/ethz-a-004351526, 2001.

Martinsen, V., Mulder, J., Austrheim, G., and Mysterud, A.: Carbon storage in low-alpine grassland soils: effects of different grazing intensities of sheep, Eur. J. Soil Sci., 62, 822-833, 2011.

Meyer, S., Leifeld, J., Bahn, M., and Fuhrer, J.: 'Land-use change in subalpine grassland soils: Effect on particulate organic carbon fractions and aggregation, accepted, J. Plant Nutr. Soil Sci., 2012.

Neff, J. C., Barger, N. N., Baisden, W. T., Fernandez, D. P., and Asner, G. P.: Soil carbon storage responses to expanding pinyonjuniper populations in southern Utah, Ecol. Appl., 19, 14051416, 2009.

Paterson, E., Midwood, A. J., and Millard, P.: Through the eye of the needle: a review of isotope approaches to quantify microbial processes mediating soil carbon balance, New Phytol., 184, 1933, 2009.

Poeplau, C., Don, A., Vesterdal, L., Leifeld, J., van Wesemael, B., Schumacher, J., and Gensior, A.: Temporal dynamics of soil organic carbon after land-use change in the temperate zone carbon response functions as a model approach, Global Change Biol., 17, 2415-2427, 2011.

Post, W. M. and Kwon, K. C.: Soil carbon sequestration and landuse change: processes and potential, Global Change Biol., 6, 
317-327, 2000.

Rasse, D., Rumpel, C., and Dignac, M.-F.: Is soil carbon mostly root carbon? Mechanisms for a specific stabilisation, Plant Soil, 269, 341-356, 2005.

Rogiers, N., Eugster, W., Furger, M., and Siegwolf, R.: Effect of land management on ecosystem carbon fluxes at a subalpine grassland site in the Swiss Alps, Theor. Appl. Clim., 80, 187203, 2005 .

Rubatscher, D.: Carbon pools and their dynamics in mountain ecosystems differing in land use, Ph.D. thesis, University of Innsbruck, Austria, 2008.

Schindlbacher, A., de Gonzalo, C., Diaz-Pinẽs, E., Gorria, P., Matthews, B., Inclãn, R., Zechmeister-Boltenstern, S., Rubio, A., and Jandl, R.: Temperature sensitivity of forest soil organic matter decomposition along two elevation gradients, J. Geophys. Res., 115, G03018, 2010.

Schmitt, M., Bahn, M., Wohlfahrt, G., Tappeiner, U., and Cernusca, A.: Land use affects the net ecosystem $\mathrm{CO}_{2}$ exchange and its components in mountain grasslands, Biogeosciences, 7, 22972309, doi:10.5194/bg-7-2297-2010, 2010.

Schulze, K., Borken, W., Muhr, J., and Matzner, E.: Stock, turnover time and accumulation of organic matter in bulk and density fractions of a Podzol soil, Eur. J. Soil Sci., 60, 567-577, 2009.

Seeber, J. and Seeber, G. U. H.: Effects of land-use changes on humus forms on alpine pastureland (Central Alps, Tyrol), Geoderma, 124, 215-222, 2005.

Seeber, J., Seeber, G. U. H., Kössler, W., Langel, R., Scheu, S., Meyer, E.: Abundance and trophic structure of macrodecomposers on alpine pastureland (Central Alps, Tyrol): effects of abandonment of pasturing, Pedobiologia, 49, 221-228, 2005.

Six, J., Elliott, E. T., Paustian, K., and Doran, J. W.: Aggregation and Soil Organic Matter Accumulation in Cultivated and Native Grassland Soils, Soil Sci. Soc. Am. J., 62, 1367-1376, 1998.

Six, J., Bossuyt, H., Degryze, S., and Denef, K.: A history of research on the link between (micro)aggregates, soil biota, and soil organic matter dynamics, Soil Tillage Res., 79, 7-31, 2004.

Steffens, M., Kölbl, A., and Kögel-Knabner, I.: Alteration of soil organic matter pools and aggregation in semi-arid steppe topsoils as driven by organic matter input, Eur. J. Soil Sci., 60, 198-212, 2009

Steffens, M., Kölbl, A., Schork, E., Gschrey, B., and KögelKnabner, I.: Distribution of soil organic matter between fractions and aggregate size classes in grazed semiarid steppe soil profiles, Plant Soil, 338, 63-81, 2011.

Stuiver, M. and Polach, H. A.: Discussion: Reporting of ${ }^{14} \mathrm{C}$ Data, Radiocarbon, 19, 355-363, 1977.

Stuiver, M., Reimer, P. J., and Braziunas, T. F.: High-precision radiocarbon age calibration for terrestrial and marine samples, Radiocarbon, 40, 1127-1151, 1998.

Swanston, C. W., Torn, M. S., Hanson, P. J., Southon, J. R., Garten, C. T., Hanlon, E. M., and Ganio, L.: Initial characterization of processes of soil carbon stabilization using forest stand-level radiocarbon enrichment, Geoderma, 128, 52-62, 2005.

Tappeiner, U., Tasser, E., Leitinger, G., Cernusca, A., and Tappeiner, G.: Effects of Historical and Likely Future Scenarios of Land Use on Above- and Belowground Vegetation Carbon Stocks of an Alpine Valley, Ecosystems, 11, 1383-1400, 2008.

Tasser, E. and Tappeiner, U.: Impact of land use changes on mountain vegetation, Appl. Veg. Sci., 5, 173-184, 2002.
Tasser, E., Tappeiner, U., and Cernusca, A.: Ecological Effects of Land-use Changes in the European Alps, in: Global Change and Mountain Regions, edited by Huber, U. M., Bugmann, H. K. M., and Reasoner, M. A., 409-420, Springer, Netherlands, 2005.

Tisdall, J. M. and Oades, J. M.: Organic matter and water-stable aggregates in soils, Eur. J. Soil Sci., 33, 141-163, 1982.

Torn, M. S., Swanston, C. W., Castanha, C., and Trumbore, S. E.: Storage and Turnover of Organic Matter in Soil, in: BiophysicoChemical Processes Involving Natural Nonliving Organic Matter in Environmental Systems, edited by: Senesi, N., Xing, B., and Huang, P. M., John Wiley \& Sons, 2009.

Trumbore, S. E.: Radiocarbon and Soil Carbon Dynamics, Annu. Rev. Earth Planet. Sci., 37, 47-66, 2009.

Trumbore, S. E., Chadwick, O. A., and Amundson, R.: Rapid Exchange between Soil Carbon and Atmospheric Carbon Dioxide Driven by Temperature Change, Science, 272, 393-396, 1996.

Vittoz, P., Randin, C., Dutoit, A., Bonnet, F., and Hegg, O.: Low impact of climate change on subalpine grasslands in the Swiss Northern Alps, Global Change Biol., 15, 209-220, 2008.

von Lützow, M., Kögel-Knabner, I., Ekschmitt, K., Flessa, H., Guggenberger, G., Matzner, E., and Marschner, B.: SOM Fractionation methods: Relevance to functional pools and to stabilization mechanisms, Soil Biol. Biochem., 39, 2183-2207, 2007.

Wardle, D. A., Bardgett, R. D., Klironomos, J. N., Setälä, H., van der Putten, W. H., and Wall, D. H.: Ecological Linkages Between Aboveground and Belowground Biota, Science, 304, 1629-1633, 2004.

Webster, R.: Statistics to support soil research and their presentation, Eur. J. Soil Sci., 52, 331-340, 2001.

West, T. O., Marland, G., King, A. W., Post, W. M., Jain, A. K., and Andrasko, K.: Carbon Management Response Curves: Estimates of Temporal Soil Carbon Dynamics, Environ. Manag., 33, 507518, 2004.

Wohlfahrt, G., Anderson-Dunn, M., Bahn, M., Balzarolo, M., Berninger, F., Campbell, C., Carrara, A., Cescatti, A., Christensen, T., Dore, S., Eugster, W., Friborg, T., Furger, M., Gianelle, D., Gimeno, C., Hargreaves, K., Hari, P., Haslwanter, A., Johansson, T., Marcolla, B., Milford, C., Nagy, Z., Nemitz, E., Rogiers, N., Sanz, M., Siegwolf, R., Susiluoto, S., Sutton, M., Tuba, Z., Ugolini, F., Valentini, R., Zorer, R., and Cernusca, A.: Biotic, Abiotic, and Management Controls on the Net Ecosystem $\mathrm{CO}_{2}$ Exchange of European Mountain Grassland Ecosystems, Ecosystems, 11, 1338-1351, 2008a.

Wohlfahrt, G., Hammerle, A., Haslwanter, A., Bahn, M., Tappeiner, U., and Cernusca, A.: Seasonal and inter-annual variability of the net ecosystem $\mathrm{CO}_{2}$ exchange of a temperate mountain grassland: Effects of weather and management, J. Geophys. Res., 113, D08110, doi:10.1029/2007JD009286, 2008b.

Zeller, V., Bahn, M., Aichner, M., and Tappeiner, U.: Impact of land-use change on nitrogen mineralization in subalpine grasslands in the Southern Alps, Biol. Fertil. Soils, 31, 441-448, 2000.

Zeller, V., Bardgett, R. D., and Tappeiner, U.: Site and management effects on soil microbial properties of subalpine meadows: a study of land abandonment along a north-south gradient in the European Alps, Soil Biol. Biochem., 33, 639-649, 2001.

Zimmermann, P., Tasser, E., Leitinger, G., and Tappeiner, U.: Effects of land-use and land-cover pattern on landscape-scale biodiversity in the European Alps, Agric., Ecosyst. Environ., 139, 13-22, 2010. 